\title{
The Biological Functions, Structure and Sources of CXCL10 and Its Outstanding Part in the Pathophysiology of Multiple Sclerosis
}

\author{
Reza Vazirinejad $^{a}$ Zahra Ahmadi $^{\mathrm{b}}$ Mohammad Kazemi Arababadi ${ }^{\mathrm{c}}$

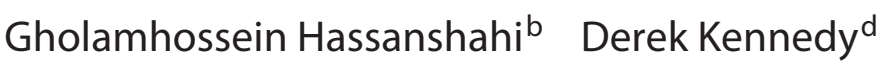 \\ a Social Determinants of Health Research Center, ${ }^{b}$ Molecular Medicine Research Center and ${ }^{\mathrm{C}}$ Immunology of Infectious

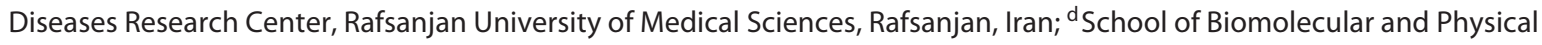 \\ Science, Eskitis Institute for Drug Discovery, Griffith University Nathan, Nathan, Qld., Australia
}

\section{Key Words}

Multiple sclerosis · Chemokine $\cdot$ CXCL10 - Pathogenesis . Inflammation

\begin{abstract}
The etiology of several autoimmune diseases, including multiple sclerosis (MS), has still not been completely clarified. MS is defined as an autoimmune disease with clinical features of a chronic, inflammatory and demyelinating autoimmune disorder which affects the central nervous system. The course of the disease includes phases of remission and relapses which can be exacerbated in both severity and duration. Chemokines, which are a subfamily of the cytokines, act as chemoattractants for a wide variety of cells, including immune cells. CXCL10 is a small protein that is defined as an 'inflammatory' chemokine and binds to CXCR3 to mediate immune responses through the activation and recruitment of leukocytes such as T cells, eosinophils, monocytes and NK cells. The aim of this review is to address recent findings regarding the relationship between CXCL10 and MS.
\end{abstract}

(c) 2014 S. Karger AG, Basel (c) 2014 S. Karger AG, Basel

$1021-7401 / 14 / 0216-0322 \$ 39.50 / 0$

\section{Introduction}

To date, the etiological aspects of many autoimmune diseases, including multiple sclerosis (MS), has yet to be characterized completely [1]. MS is an inflammatory disorder of the central nervous system (CNS) which is defined by loss of myelin, gliosis and different degrees of axonal and oligodendrocyte pathology [2]. MS usually commences in early adulthood, with paralysis, sensory disturbances, lack of coordination and visual impairment among its most frequent features [3]. The disease often begins with an 'attack' or 'flare' that lasts from a few days to weeks and is followed by remission that most often lasts from a few months to years $[4,5]$. The variable course of the disease may be reflected in the differences seen at the morphological level by magnetic resonance imaging and histopathologic evaluations of the CNS, which also vary significantly [6]. Although the main causes of MS are yet to be fully understood, the disease mechanisms are often inferred from the effector phase of an animal model of MS: experimental autoimmune encephalomyelitis (EAE) [7]. The disease course of relaps-

\section{KARGER}

E-Mail karger@karger.com

www.karger.com/nim
Dr. Gholamhossein Hassanshah

Molecular Medicine Research Center

Rafsanjan University of Medical Sciences

Rafsanjan (Iran)

E-Mail ghhassanshahi@rums.ac.ir 
ing-remitting MS (RRMS) involves periods of clinical remission and unpredictable relapses or exacerbations, differing in both severity and duration. Following several years of an RR phase, MS patients may enter a secondary progressive phase (SPMS) where the onset of symptoms and nerve functions gradually worsen either with or without relapses [8].

Although the underlying etiological cause and pathogenesis of MS are unknown, the current suggestions favor MS as an autoimmune inflammatory disorder of the CNS in which autoreactive $\mathrm{T}$ lymphocytes recognize CNSspecific proteins, leading to inflammation and demyelination. According to the cellular infiltrates detected in the brain and cerebrospinal fluid (CSF) from patients alongside data from rodent models, including EAE, MS is largely considered to be a CD4+ T helper 1 (Th1)-mediated inflammatory disease [9]; however, CD4+ Th17 effector $\mathrm{T}$ cells are postulated to have more important roles $[10,11]$. In the EAE model, it has been demonstrated that the injection of myelin components into susceptible animals resulted in a CD4+-mediated autoimmune disease that shares similarities with MS [12]. EAE can also be induced by the adoptive transfer of encephalitogenic CD4+ $T$ cells into a naive animal $[12,13]$. It appears that white blood cells, including lymphocytes, are chemoattracted to the MS plaques in response to chemokines. Immunohistochemical studies demonstrated that several chemokine ligands, in parallel with their receptors, are present in MS lesions. Therefore, it seems that chemokines play crucial roles in the pathogenesis of MS. Chemokines are a subfamily of the larger family of cytokines that serve as recruiter/migratory factors for a wide spectrum of cells, and their target cells express appropriate transmembrane $G$ protein chemokine receptors. Chemokines are further subdivided into $\mathrm{C}, \mathrm{CC}, \mathrm{CX} 3 \mathrm{C}$ and $\mathrm{CXC}$ subgroups according to the position of conserved cysteine motifs in their structure [14]. CXCL10 (interferon- $\gamma$-inducible protein 10 , previously called IP-10) was initially discovered as a chemokine which is induced by interferon (IFN)- $\gamma$ and is produced by a wide range of cell types including monocytes [15], neutrophils [16], endothelial cells [17], keratinocytes [18], fibroblasts [19], mesenchymal cells [20], dendritic cells [21], hepatocytes [22] and astrocytes [23]. CXCL10 binds to CXCR3, which is discussed in the next section. Recent evidence has indicated that serum/tissue expression of CXCL10 is increased in MS [24]. Both CXCL10 and CXCR3 are crucial for leukocyte trafficking and homing to inflamed tissues as well as the perpetuation of inflammation which leads to tissue damage [25].

CXCL10 and the Pathogenesis of MS
Th1 and Th2 subsets of lymphocytes can be defined by their expression of chemokine receptors. CXCR3 is associated with the Th1 phenotype and is preferentially expressed on activated Th1 cells [26]. MS is considered a Th1-dependent disease in which Th1-related cytokines and chemokines are increased during the course of the disorder [27]. Interestingly, elevated percentages of T cells expressing the CXCR 3 chemokine receptor in peripheral blood and CSF during the active phase of MS suggest that CXCR3 plays important roles in the induction of active demyelinating in MS brain lesions [28, 29]. Based on the clinical and experimental observations discussed above, this review explores the relationship between CXCL10 and MS as an autoimmune disorder.

\section{CXCL10 Biostructure and Functions}

It is well documented that chemokines - and more specifically CXCL10 - are produced by several cell and tissue types and exhibit pleiotropic effects on a wide range of biological processes including immunity, angiogenesis and organ-specific metastasis of cancers. The role of CXCL10 in these processes makes it a promising therapeutic target for various diseases. However, an identification of the structural properties and mechanism of action of CXCL10 needs to be made if CXCL10 is to be used as a worthwhile therapeutic target for treatment of the aforementioned pathological conditions. CXCL10 was initially identified in human U937 cells (a histiocytic lymphoma cell line with monocytic characterization and origin) and from human placenta and spleen as an IFN$\gamma$-inducible product [30]; mob- 1 and crg- 2 are the rat and mouse homologs of human chemokine CXCL10, and they share 70 and $78 \%$ amino acid homology with these proteins, respectively [31]. Like other members of the chemokine subfamily, CXCL10 is a small-molecularweight protein $(10 \mathrm{kDa})$ which was functionally described as an 'inflammatory' chemokine. Furthermore, the lack the ELR tripeptide (Arg-Leu-Glu) motif in the vicinity of CXC residues characterizes CXCL10 as an inhibitor of neovascularization; hence, it acts as an 'angiostatic' (antiangiogenic) chemokine [32]. The CXCL10 gene is located on chromosome 4 , contains 4 exons and 3 introns and encodes a protein of 98 amino acids [19, 33]. CXCL10 is transcriptionally regulated in response to external stimuli such as IFN- $\gamma$ and lipopolysaccharides (LPS) by a region of 230 nucleotides upstream from the transcriptional start site. This area contains several important regulatory elements, as follows: (a) 2 sites for nu-

Neuroimmunomodulation 2014;21:322-330 
Fig. 1. External stimuli which affect CXCL10 and the intracellular events leading to its expression (adopted from Ahmadi et al. [30]). Signals are initiated by receptor-ligand interaction, either involving growth factors or cytokines, and stress stimuli are illustrated. Process of receptor binding. Protein complexes are recruited to the receptor. Resulting activation of corresponding signaling events and initiation of activation of their downstream targets. $\mathrm{CS}=$ Cytokine stimulation; $\mathrm{CRE}=$ cytokine response element; HSRE $=$ HS response element; US = unknown stimulation; ERK = extracellular signal-regulated kinase; I $\mathrm{B}=$ inhibitor of NF- $\kappa \mathrm{B}$; JNK = c-Jun N-terminal kinase; $\mathrm{MEK}=$ mitogen-activated protein kinase kinase; NIK = NF- $\kappa \mathrm{B}$-inducing kinase; $\mathrm{PI} 3 \mathrm{~K}=$ phosphoinositide 3-kinase; $\mathrm{UV}=$ ultra violet light.

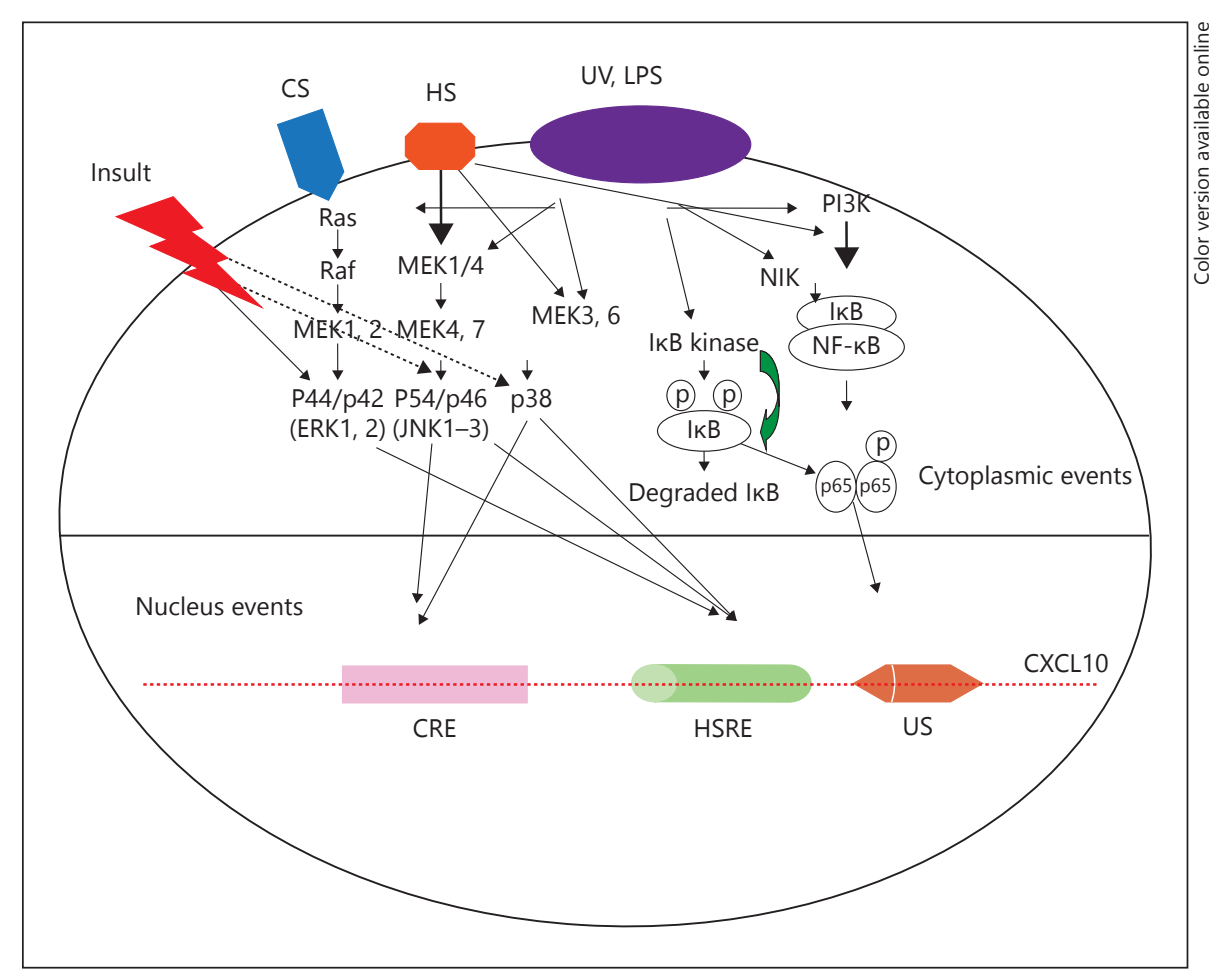

clear factor- $\kappa \mathrm{B}(\mathrm{NF}-\kappa \mathrm{B})$; (b) 1 site for activator protein 1 ; (c) 1 site for interferon-stimulated response element (ISRE); and (d) 1 site for binding of heat shock (HS) factors (fig. 1) [34].

CXCL9, CXCL10 and CXCL11 all share CXCR3 as a common receptor for their activities. CXCR3 has two different isoforms: CXCR3-A and CXCR3-B. The most recent studies revealed that the CXCR3 isoforms differentially regulate cell function. The CXCL10/CXCR3-A axis contributes to the induction of chemotaxis and proliferation in various cell types $[35,36]$, whereas the CXCL10/CXCR3-B axis inhibits migration and proliferation but induces apoptosis [36,37]. Additionally, CXCL10 is reported to act as an antiangiogenic/antitumor protein $[37,38]$. Although the precise biological functions of CXCL10 are yet to be completely identified, several lines of evidence have demonstrated that this chemokine is involved in the following physiological and pathological situations: (a) chemoattraction of macrophages, monocytes and activated T and NK cells [3941]; (b) modulation of $\mathrm{T}$ cell development and function [42, 43]; (c) inhibition of in vitro colony formation by early human bone marrow progenitor cells [44]; (d) stimulation of $\mathrm{T}$ cell adhesion to endothelial cells [45]; (e) induction of NK cell migration along with NK cell- mediated cytolysis; (f) in antiangiogenesis (including antitumor angiogenesis) $[24,30,46]$, and (g) by mitogenic and chemotactic effects on vascular smooth muscle cells $[43,44]$.

\section{CXCL10 Signal Transduction}

Synergy was observed between tumor necrosis factor (TNF) $-\alpha$ and IFN- $\gamma$ regarding the induction of CXCL10 expression by different cell systems such as keratinocytes and hepatocytes. This synergistic effect is facilitated by $\mathrm{NF}-\kappa \mathrm{B}$ and ISRE in the promoter of CXCL10 $[47,48]$. In isolated and cultured pancreatic acinar cells, cholecystokinin (CCK8) was shown to increase CXCL10 via a pathway regulated by NF- $\kappa \mathrm{B}$ activation which was blocked by PDTC (pyrrolidine dithiocarbamate, an NF- $\kappa \mathrm{B}$ inhibitor) through a mechanism which repressed inhibitor of NF- $\kappa \mathrm{B}-\alpha$ degradation and in turn caused induced CXCL10 expression [49]. NF- $\kappa B$ activation and subsequent CXCL10 expression, in response to CCK8, was reported to be mediated by protein kinase $\mathrm{C}$ in parallel with increased intracellular $\mathrm{Ca}^{2+}[49,50]$. Evidence also indicates that stimulation of keratinocytes with TNF- $\alpha$ and IFN- $\gamma$ induced CXCL10 in a concentration- and time- 
dependent manner, mediated by activation of the protein kinase $C$ pathway $[47,51]$. In a similar fashion, primary human kidney mesangial cells, stimulated by TNF- $\alpha$ and/ or IFN- $\gamma$, also produced CXCL10 in an NF- $\mathrm{KB}$-dependent pathway, and co-operation between the ISRE and NF- $\mathrm{KB}$ sites on the CXCL10 promoter were responsible for this action [52]. TNF- $\alpha$ and IFN- $\gamma$ employ STAT1 $\alpha$ (signal transducer and activator of transcription $1 \alpha$ ) and NF- $\kappa B$, respectively, for CXCL10 expression in human fibroblast cell lines $[47,52,53]$ as well as LPS-stimulated Kupffer cells [54].

\section{Role of CXCL10 in MS}

Currently there is limited information available concerning the role of chemokines in MS, especially at the serum level. In MS, chemokines act both as leukocytemigratory factors and mediators of proinflammatory reactions (both of which promote the process of demyelination) [55]. Chemokines regulate the expression of adhesion molecules and therefore aid transendothelial migration of autoreactive immune-compatible cells through the blood-brain barrier [56].

\section{Serum and CSF Levels of CXCL10 in MS Patients}

The levels of CXCL10 in circulating blood were previously found to be elevated in IFN- $\beta$-treated MS patients when compared with those left untreated [57]. Altered serum levels of other members of the chemokine family such as CCL11 indicated that they are not directly associated with IFN- $\beta$ treatment and are regulated by Th 2 cellmediated cytokines [58].

Sørensen et al. [59] reported that CXCL10 levels were higher in CSF specimens collected from patients suffering from active MS as opposed to CSF measurements made in neurological subjects with noninflammatory conditions. More than $90 \%$ of the T cells present in the CSF of MS patients expressed CXCR3, which is significantly more than those found in peripheral blood. Present observations are in accordance with the fundamental role of the CXCL10/CXCR3 axis in the pathogenesis of MS [29, $59,60]$.

Sørensen et al. [61] in another study also revealed that CXCL10 levels were elevated in the CSF of MS patients and that this was associated with increased leukocyte numbers in CSF $[61,62]$. It could be reasonable to assume that the induction of CXCL10 (especially in RRMS patients) is probably related to stimulation of regulatory motifs present at the upstream transcriptional start site of the CXCL10 promoter. This regulatory region of the CXCL10 gene contains motifs for a variety of signal transduction pathways including HS IFN- $\gamma$ and NF- $\kappa$ B response elements [63, 64] (fig. 1) [30].

Scarpini et al. [65] assessed CXCL10 in both CSF and serum of RRMS and SPMS patients, but not in primary progressive (PP) MS patients, and observed its elevation. Similarly, Sprenger et al. [66] indicated that CXCL10 was significantly enhanced in the CSF and serum of patients affected by other inflammatory neurological diseases. The results from all these studies are in line with data collected by Franciotta et al. [67] as well as our own data [62], which showed elevated serum levels of CXCL10 in RRMS patients. The increased CXCL10 levels and the increase in cells expressing its receptor, CXCR3, in the CSF of MS patients during the active phase of the disease in the intrathecal compartment have also been well documented [59]. Additionally, Comini-Frota et al. [68] reported that serum CXCL10 levels were higher in MS patients than in controls, and this is interesting because they also recorded considerable increases in expression following $36 \mathrm{~h}$ of IFN- $\beta 1$ a or IFN- $\beta 1 b$ therapy.

Again, studies showed that CXCL10 expression was elevated in the CSF of MS patients and this was associated with demyelination in CNS tissue sections. Furthermore, this was tightly correlated with CXCR3 expression [69]. Christophi et al. [70] reported that quantities of CXCL10 and caspase 1 were both elevated in peripheral blood mononuclear cells of MS patients. However, treatment with either IFN- $\beta$ 1a formulations (Rebif or Avonex) significantly upregulated the expression of both CXCL10 and caspase 1 , which was mediated by the activation of the STAT1 pathway. Moreover, they observed that CXCL10 expression (at the mRNA level) was induced more by the use of Rebif than Avonex. Therefore it appears that in addition to IFN- $\gamma$, TNF- $\alpha$ and proinflammatory cytokines CXCL10 is also an IFN- $\beta$-inducible gene product involved in MS pathogenesis [61, 71, 72]; however, conflicting reports claimed that chemokine expression was also suppressed by IFN- $\beta$ [73].

In contrast to the aforementioned studies which documented the elevation of CXCL10 levels in MS patients, Sørensen et al. [61] reported that CXCL10 remained significantly unchanged within the CSF 1 week following fulfillment of a 15-day course of oral high-dose methylprednisolone in MS patients. This does not exclude an effect during or immediately after treatment. However, other effects of methylprednisolone appear to be related to the properties of this compound during the processes of disease remission observed after treatment $[74,75]$. 
Table 1. Summary of the literature reviewed concerning the immune-related diseases reported

\begin{tabular}{|c|c|c|c|c|c|}
\hline Denmark & 38 & $\begin{array}{l}21 \text { female } \\
17 \text { male }\end{array}$ & $\begin{array}{l}\text { Patients: } 936 \pm 72 \mathrm{pg} / \mathrm{ml} \\
\text { Controls: } 319 \pm 43 \mathrm{pg} / \mathrm{ml}\end{array}$ & - & 59 \\
\hline Denmark & 48 & ND & - & $\begin{array}{l}\text { Patients: } 2.6 \mathrm{ng} / \mathrm{ml} \\
\text { Controls: } 319 \pm 43 \mathrm{pg} / \mathrm{ml}(\text { mean } \pm \text { SEM })\end{array}$ & 61 \\
\hline Denmark & 36 & ND & - & $\begin{array}{l}\text { Patients - with clinically definite MS: } 3.3 \mathrm{ng} / \mathrm{ml} \\
\text { Controls: } 1.82 \mathrm{ng} / \mathrm{ml}\end{array}$ & 61 \\
\hline Denmark & 26 & ND & - & $\begin{array}{l}\text { Patients - after } 3 \text { weeks in either placebo group: } 3.1 \mathrm{ng} / \mathrm{ml} \\
\text { Controls: } 1.82 \mathrm{ng} / \mathrm{ml}\end{array}$ & 61 \\
\hline Denmark & 10 & ND & $\begin{array}{l}\text { Patients: median of } 0 \mathrm{ng} / \mathrm{ml} \\
\text { Controls: } 1.82 \mathrm{ng} / \mathrm{ml}\end{array}$ & - & 61 \\
\hline Italy & 39 & $\begin{array}{l}34 \text { female } \\
5 \text { male }\end{array}$ & $\begin{array}{l}\text { Patients - active RRMS: } 289 \pm 96 \mathrm{pg} / \mathrm{ml} \\
\text { (mean } \pm \text { SEM) } \\
\text { Controls: } 78 \pm 15 \mathrm{pg} / \mathrm{ml}(\text { mean } \pm \text { SEM })\end{array}$ & $\begin{array}{l}\text { Patients - active RRMS: } 453 \pm 6 \mathrm{pg} / \mathrm{ml}(\text { mean } \pm \text { SEM }) \\
\text { Controls: } 79 \pm 27 \text { pg/ml (mean } \pm \text { SEM) }\end{array}$ & 65 \\
\hline Italy & 14 & $\begin{array}{l}13 \text { female } \\
1 \text { male }\end{array}$ & $\begin{array}{l}\text { Patients - stable RRMS: } 258 \pm 129 \mathrm{pg} / \mathrm{ml} \\
(\text { mean } \pm \text { SEM) } \\
\text { Controls: } 78 \pm 15 \mathrm{pg} / \mathrm{ml}(\text { mean } \pm \text { SEM })\end{array}$ & $\begin{array}{l}\text { Patients - stable RRMS: } 293 \pm 43 \mathrm{pg} / \mathrm{ml}(\text { mean } \pm \text { SEM }) \\
\text { Controls: } 79 \pm 27 \mathrm{pg} / \mathrm{ml}(\text { mean } \pm \text { SEM })\end{array}$ & 65 \\
\hline Italy & 12 & $\begin{array}{l}8 \text { female } \\
4 \text { male }\end{array}$ & $\begin{array}{l}\text { Patients - SPMS: } 221 \pm 52 \mathrm{pg} / \mathrm{ml}(\text { mean } \pm \text { SEM }) \\
\text { Controls: } 78 \pm 15 \mathrm{pg} / \mathrm{ml}(\text { mean } \pm \text { SEM })\end{array}$ & $\begin{array}{l}\text { Patients - SPMS: } 424 \pm 130 \mathrm{pg} / \mathrm{ml}(\text { mean } \pm \text { SEM }) \\
\text { Controls: } 79 \pm 27 \mathrm{pg} / \mathrm{ml}(\text { mean } \pm \text { SEM })\end{array}$ & 65 \\
\hline Italy & 38 & ND & $\begin{array}{l}\text { Patients - acute MS: } 331 \pm 66 \mathrm{pg} / \mathrm{ml} \\
\text { Controls: } 60 \pm 8 \mathrm{pg} / \mathrm{ml}\end{array}$ & $\begin{array}{l}\text { Patients - acute MS: } 118 \pm 16 \mathrm{pg} / \mathrm{ml} \\
\text { Controls: } 22 \pm 1 \mathrm{pg} / \mathrm{ml}\end{array}$ & 67 \\
\hline Italy & 18 & $\begin{array}{l}10 \text { female } \\
8 \text { male }\end{array}$ & $\begin{array}{l}\text { Patients - active phase: pretreatment with } \\
\text { methylprednisolone } 175 \pm 95 \mathrm{pg} / \mathrm{ml}(\text { mean } \pm \text { SEM) } \\
\text { Controls: } 60 \pm 8 \mathrm{pg} / \mathrm{ml}\end{array}$ & $\begin{array}{l}\text { Patients - active phase: pretreatment with methylprednisolone } \\
126 \pm 31 \mathrm{pg} / \mathrm{ml}(\mathrm{mean} \pm \mathrm{SEM}) \\
\text { Controls: } 22 \pm 1 \mathrm{pg} / \mathrm{ml}\end{array}$ & 67 \\
\hline Italy & 18 & $\begin{array}{l}10 \text { female } \\
8 \text { male }\end{array}$ & $\begin{array}{l}\text { Patients - active phase: } \\
\text { undergoing therapy with 6-methylprednisolone } \\
(1 \mathrm{~g} \text { daily) after } 6 \text { days } \\
102 \pm 22 \mathrm{pg} / \mathrm{ml}(\mathrm{mean} \pm \mathrm{SEM}) \\
\text { Controls: } 60 \pm 8 \mathrm{pg} / \mathrm{ml}\end{array}$ & $\begin{array}{l}\text { Patients - active phase: undergoing therapy with } \\
6 \text {-methylprednisolone }(1 \mathrm{~g} \text { daily) after } 6 \text { days } \\
89 \pm 30 \mathrm{pg} / \mathrm{ml}(\text { mean } \pm \text { SEM }) \\
\text { Controls: } 22 \pm 1 \mathrm{pg} / \mathrm{ml}\end{array}$ & 67 \\
\hline Italy & 15 & $\begin{array}{l}9 \text { female } \\
6 \mathrm{mal}\end{array}$ & $\begin{array}{l}\text { Patients - stable phase: } \\
\text { pretreatment with IFN- } \beta 1 \mathrm{a} 63 \pm 10 \mathrm{pg} / \mathrm{ml} \\
\text { (mean } \pm \text { SEM) } \\
\text { Controls: } 60 \pm 8 \mathrm{pg} / \mathrm{ml}\end{array}$ & - & 67 \\
\hline Italy & 15 & $\begin{array}{l}9 \text { female } \\
6 \text { male }\end{array}$ & $\begin{array}{l}\text { Patients - stable phase: undergoing therapy with } \\
\text { IFN- } \beta 1 \mathrm{a}(6 \mathrm{MU} \text { weekly) after } 6 \text { months } 61 \pm 11 \\
\mathrm{pg} / \mathrm{ml} \text { (mean } \pm \text { SEM) } \\
\text { Controls: } 60 \pm 8 \mathrm{pg} / \mathrm{ml}\end{array}$ & - & 67 \\
\hline
\end{tabular}


Table 1. (Continued)

\begin{tabular}{lcllll}
\hline Country & $\begin{array}{l}\text { Sample } \\
\text { size, } \mathrm{n}\end{array}$ & Sex, $\mathrm{n}$ & Serum levels of CXCL10 & CSF levels of CXCL10 & $\begin{array}{l}\text { Ref. } \\
\text { No. }\end{array}$ \\
\hline Denmark & 21 & $\begin{array}{c}17 \text { female } \\
4 \text { male }\end{array}$ & - & $\begin{array}{l}\text { Patients: } 1.64 \mathrm{ng} / \mathrm{ml} \\
\text { Controls: } 0.59 \mathrm{ng} / \mathrm{ml}\end{array}$ \\
\hline USA & 32 & $\begin{array}{l}22 \text { female } \\
10 \text { male }\end{array}$ & $\begin{array}{l}\text { Patients }- \text { untreated MS: } 3.2 \pm 1.3 \mathrm{ng} / \mathrm{ml} \\
\text { Controls: } 1 \pm 0.2 \mathrm{ng} / \mathrm{ml}\end{array}$ & - \\
\hline USA & 10 & $\begin{array}{l}7 \text { female } \\
3 \text { male }\end{array}$ & $\begin{array}{l}\text { Patients }- \text { Rebif MS patients: } 12.4 \pm 3.3 \mathrm{ng} / \mathrm{ml} \\
\text { Controls: } 1 \pm 0.2 \mathrm{ng} / \mathrm{ml}\end{array}$ & - \\
\hline USA & 10 & 7 female & $\begin{array}{l}\text { Patients }- \text { Avonex MS patients: } 6.3 \pm 2.4 \mathrm{ng} / \mathrm{ml} \\
\text { C male }\end{array}$ & Controls: $1 \pm 0.2 \mathrm{ng} / \mathrm{ml}$ & - \\
\hline
\end{tabular}

$\mathrm{ND}=$ Not determined .

However, the current observations are in agreement with the prominent role of CXCL10 in the maintenance of intrathecal inflammation and may partly explain the mechanism(s) by which high doses of oral methylprednisolone do not influence the recurrence of disease activity [74]. Thus, treatment with IFN- $\beta$ appears to be the preferred regime leading to decreased intrathecal inflammation [76].

More recent reports by Mellergård et al. [77] verified that following a period of 1 year of treatment with the newly introduced anti-MS reagent natalizumab, a panel of cytokines and chemokines were decreased. They demonstrated that, in addition to declined levels of proinflammatory cytokines such as interleukin (IL)-1 $\beta$, IL-2, IL-4, IL-5, IL-6, IL-8, IL-10, TNF- $\alpha$, IFN- $\delta$ and granulocyte/ macrophage colony-stimulating factor, several chemokines including CXCL9, CXCL10, CXCL11, CCL17 and CCL22 were also decreased in the blood and CSF of RRMS patients following 1 year of treatment with natalizumab.

\section{Expression of CXCL10 in EAE Animal Models and MS Lesions}

Astrocytes are also the source of CXCL10 in both human and mouse EAE models [29, 59, 78], and evidence from these models demonstrates that both TNF- $\alpha$ and IFN- $\gamma$ (as members of the proinflammatory cytokines) regulate CXCL10 expression in cell lines [79] as well as a rat model [48].

Immunocytochemical studies confirmed the presence of CXCL10 in postmortem CNS tissues from MS patients. In lesions where demyelination was active and ongoing, CXCL10 was predominantly expressed by both macrophages (present inside the plaque) and reactive astrocytes in the surrounding parenchyma. Correspondingly, CXCR3 was also expressed by $\mathrm{T}$ cells and astrocytes within the plaques, which may strongly suggest an autocrine fashion of CXCL10 expression by these cells $[29,60]$.

Salmaggi et al. [80] demonstrated that human brain microvascular endothelial cells and astrocytes express IFN- $\gamma$-inducible chemokines CXCL10 and CXCL11 in response to inflammatory stimuli. Moreover, in autoimmune pathologies including MS, both $\delta$ T cells (V $\delta 1$ and $\mathrm{V} \delta 2$ cells) exhibit differential expression of cell adhesion molecules as well as chemokine receptors. V $\delta 1$ cells express CXCR4, while V $\delta 2$-type cells express CXCR3, and these cell populations transmigrate across endothelial cells in response to CXCL12 and CXCL10 [81]. Buttmann et al. [82] investigated a panel of IFN-inducible chemokines including CXCL10 and, using in situ hybridization analysis, corroborated a strong expression of CXCL10 mRNA by infiltrating immune cells and basal keratinocytes into patients in the IFN- $\beta$-injected areas. Table 1 shows a summary of the literature reviewed concerning the immune-related diseases reported.

\section{Conclusions}

Overall, based on the latest information available in the literature regarding the role of CXCL10 in the pathogenesis of MS, the authors of the present article propose that CXCL10 plays a critical role during symptomatic inflammatory demyelination events that occur in the pathogenesis of MS. However, this is inconsistent with the evidence that exists regarding the CSF and serum levels of CXCL10 in the PP form of MS, in which less inflamma- 
tion is observed [83]. Indeed this is more similar to what is observed in noninflammatory neurological diseases.

Finally, due to the complex manifestations of MS, more characterization - with particular attention to accuracy - is required with regard to surveying several other aspects of the disease. To achieve this, the authors of the present article believe that it is worthwhile to more accurately examine the role of CXCL10 and its corresponding receptor (e.g. CXCR3) during the pathogenesis of MS using animal-based EAE models.

\section{Acknowledgement}

This project was supported by a grant from the Rafsanjan University of Medical Sciences.

\section{Disclosure Statement}

None of the authors of this study declare any conflict of interest.

\section{References}

1 Bach JF, Chatenoud L: Tolerance to islet autoantigens in type 1 diabetes. Annu Rev Immunol 2001;19:131-161.

-2 Rubin SM: Management of multiple sclerosis: an overview. Dis Mon 2013;59:253-260.

$\checkmark 3$ Ozakbas S, Kaya D, Idiman E: Early onset multiple sclerosis has worse prognosis than adult onset multiple sclerosis based on cognition and magnetic resonance imaging. Autoimmune Dis 2012;2012:563989.

4 Lin GY, Wang CW, Chiang TT, Peng GS, Yang FC: Multiple sclerosis presenting initially with a worsening of migraine symptoms. J Headache Pain 2013;14:70.

5 Rotondi M, Batocchi AP, Coperchini F, Caggiula $\mathrm{M}$, Zerbini F, Sideri R, Leporati $\mathrm{P}$, Nociti V, Frisullo G, Mirabella M: Severe disability in patients with relapsing-remitting multiple sclerosis is associated with profound changes in the regulation of leptin secretion. Neuroimmunomodulation 2013;20 341-347.

-6 Gil Moreno MJ, Cerezo García M, Marasescu R, Pinel González A, López Álvarez L, Aladro Benito Y: Neuropsychological syndromes in multiple sclerosis. Psicothema 2013;25:452460.

7 Agrawal SM, Yong VW: Immunopathogenesis of multiple sclerosis. Int Rev Neurobiol 2007;79:99-126.

-8 Gandhi KS, McKay FC, Diefenbach E, Crossett B, Schibeci SD, Heard RN, Stewart GJ, Booth DR, Arthur JW: Novel approaches to detect serum biomarkers for clinical response to interferon- $\beta$ treatment in multiple sclerosis. PLoS One 2010;5:e10484

$\checkmark 9$ LaSalle JM, Ota K, Hafler DA: Presentation of autoantigen by human $\mathrm{T}$ cells. J Immunol 1991;147:774-780.

$>10$ Bettelli E, Carrier Y, Gao W, Korn T, Strom TB, Oukka M, Weiner HL, Kuchroo VK: Reciprocal developmental pathways for the generation of pathogenic effector $\mathrm{T}_{\mathrm{H}} 17$ and regulatory T cells. Nature 2006;441:235238 .

11 Iwakura Y, Ishigame H: The IL-23/IL-17 axis in inflammation. J Clin Invest 2006;116 $1218-1222$.
12 Martin R, McFarland HF, McFarlin DE: Immunological aspects of demyelinating diseases. Annu Rev Immunol 1992;10:153187.

13 Pettinelli CB, McFarlin DE: Adoptive transfer of experimental allergic encephalomyelitis in SJL/J mice after in vitro activation of lymph node cells by myelin basic protein: requirement for Lyt 1+2- T lymphocytes. J Immunol 1981;127:1420-1423.

14 Derakhshan R, Arababadi MK, Ahmadi Z, Karimabad MN, Salehabadi VA, Abedinzadeh M, Khorramdelazad H, Balaei P, Kennedy D, Hassanshahi G: Increased circulating levels of SDF-1 (CXCL12) in type 2 diabetic patients are correlated to disease state but are unrelated to polymorphism of the SDF- $1 \beta$ gene in the Iranian population. Inflammation 2012;35:900-904.

15 Ciesielski CJ, Andreakos E, Foxwell BM, Feldmann M: TNFa-induced macrophage chemokine secretion is more dependent on NF$\kappa \mathrm{B}$ expression than lipopolysaccharides-induced macrophage chemokine secretion. Eur J Immunol 2002;32:2037-2045.

16 Ohmori Y, Hamilton TA: The interferonstimulated response element and a $\kappa \mathrm{B}$ site mediate synergistic induction of murine IP-10 gene transcription by IFN- $\gamma$ and TNF- $\alpha$. J Immunol 1995;154:5235-5244.

17 Shields PL, Morland CM, Salmon M, Qin S, Hubscher SG, Adams DH: Chemokine and chemokine receptor interactions provide a mechanism for selective $\mathrm{T}$ cell recruitment to specific liver compartments within hepatitis C-infected liver. J Immunol 1999; 163:62366243.

18 Dillman JF 3rd, McGary KL, Schlager JJ: An inhibitor of p38 MAP kinase downregulates cytokine release induced by sulfur mustard exposure in human epidermal keratinocytes. Toxicol In Vitro 2004;18:593-599.

19 Ohmori Y, Hamilton TA: Cell type and stimulus specific regulation of chemokine gene expression. Biochem Biophys Res Commun 1994; 198:590-596.

20 Treacy O, Ryan AE, Heinzl T, O’Flynn L, Cregg M, Wilk M, Odoardi F, Lohan P,
O’Brien T, Nosov M, Ritter T: Adenoviral transduction of mesenchymal stem cells: in vitro responses and in vivo immune responses after cell transplantation. PLoS One 2012; 7:e42662.

$\checkmark 21$ Ge MQ, Ho AW, Tang Y, Wong KH, Chua BY, Gasser S, Kemeny DM: NK cells regulate CD8+ T cell priming and dendritic cell migration during influenza A infection by IFN- $\gamma$ and perforin-dependent mechanisms. J Immunol 2012;189:2099-2109.

22 Zeissig S, Murata K, Sweet L, Publicover J, Hu Z, Kaser A, Bosse E, Iqbal J, Hussain MM, Balschun K, Röcken C, Arlt A, Günther R, Hampe J, Schreiber S, Baron JL, Moody DB, Liang TJ, Blumberg RS: Hepatitis $\mathrm{B}$ virus-induced lipid alterations contribute to natural killer $\mathrm{T}$ cell-dependent protective immunity. Nat Med 2012;18: 1060-1068.

23 Hassanshahi G, Patel SS, Jafarzadeh AA, Dickson AJ: Expression of CXC chemokine IP-10/Mob-1 by primary hepatocytes following heat shock. Saudi Med J 2007;28:514518.

24 Rotondi M, Chiovato L, Romagnani S, Serio M, Romagnani P: Role of chemokines in endocrine autoimmune diseases. Endocr Rev 2007;28:492-520

-25 Hassanshahi G, Jafarzadeh A, Esmaeilzadeh B, Arababadi MK, Yousefi H, Dickson AJ: Assessment of NK cells response to hepatocyte derived chemotactic agents. Pak J Biol Sci 2008;11:1120-1125.

26 Bonecchi R, Bianchi G, Bordignon PP, D’Ambrosio D, Lang R, Borsatti A, Sozzani S, Allavena P, Gray PA, Mantovani A, Sinigaglia F: Differential expression of chemokine receptors and chemotactic responsiveness of type $1 \mathrm{~T}$ helper cells (Th1s) and Th2s. J Exp Med 1998;187:129-134.

-27 Arababadi MK, Mosavi R, Khorramdelazad H, Yaghini N, Zarandi ER, Araste M, Pourali R, Nekhei Z, Kennedy D: Cytokine patterns after therapy with Avonex ${ }^{\circledR}$, Rebif ${ }^{\circledR}$, Betaferon ${ }^{\circledR}$ and CinnoVex ${ }^{\mathrm{TM}}$ in relapsing-remitting multiple sclerosis in Iranian patients. Biomark Med 2010;4:755-759. 
-28 Sørensen TL, Tani M, Jensen J, Pierce V, Lucchinetti C, Folcik VA, Qin S, Rottman J, Sellebjerg F, Strieter RM, Frederiksen JL, Ransohoff RM: Expression of specific chemokines and chemokine receptors in the central nervous system of multiple sclerosis patients. J Clin Invest 1999;103:807-815.

-29 Balashov KE, Rottman JB, Weiner HL, Hancock WW: $\mathrm{CCR}^{+}$and $\mathrm{CXCR}^{+} \mathrm{T}$ cells are increased in multiple sclerosis and their ligands MIP- $1 \alpha$ and IP-10 are expressed in demyelinating brain lesions. Proc Natl Acad Sci USA 1999;96:6873-6878.

30 Ahmadi Z, Arababadi MK, Hassanshahi G: CXCL10 activities, biological structure, and source along with its significant role played in pathophysiology of type I diabetes mellitus. Inflammation 2013;36:364-371.

- 31 Liang P, Averboukh L, Zhu W, Pardee AB: Ras activation of genes: Mob-1 as a model. Proc Natl Acad Sci USA 1994;91:1251512519.

- 32 Strieter RM, Polverini PJ, Kunkel SL, Arenberg DA, Burdick MD, Kasper J, Dzuiba J, van Damme J, Walz A, Marriott D, et al: The functional role of the ELR motif in CXC chemokine-mediated angiogenesis. J Biol Chem 1995;270:27348-27357.

- 33 Deng W, Ohmori Y, Hamilton TA: Mechanisms of IL-4-mediated suppression of IP-10 gene expression in murine macrophages. J Immunol 1994;153:2130-2136.

-34 Ohmori Y, Hamilton TA: Cooperative interaction between interferon (IFN) stimulus response element and $\kappa \mathrm{B}$ sequence motifs controls IFN $\gamma$ - and lipopolysaccharidestimulated transcription from the murine IP-10 promoter. J Biol Chem 1993;268:66776688.

- 35 Kelsen SG, Aksoy MO, Yang Y, Shahabuddin S, Litvin J, Safadi F, Rogers TJ: The chemokine receptor CXCR3 and its splice variant are expressed in human airway epithelial cells. Am J Physiol Lung Cell Mol Physiol 2004;287:L584-L591.

- 36 Lasagni L, Francalanci M, Annunziato F, Lazzeri E, Giannini S, Cosmi L, Sagrinati C, Mazzinghi B, Orlando C, Maggi E, Marra F, Romagnani S, Serio M, Romagnani P: An alternatively spliced variant of CXCR3 mediates the inhibition of endothelial cell growth induced by IP-10, Mig, and I-TAC, and acts as functional receptor for platelet factor 4 . J Exp Med 2003;197:1537-1549.

- 37 Bodnar RJ, Yates CC, Wells A: IP-10 blocks vascular endothelial growth factor-induced endothelial cell motility and tube formation via inhibition of calpain. Circ Res 2006;98: 617-625.

- 38 Bodnar RJ, Yates CC, Rodgers ME, Du X, Wells A: IP-10 induces dissociation of newly formed blood vessels. J Cell Sci 2009;122: 2064-2077.

-39 Taub DD, Lloyd AR, Conlon K, Wang JM, Ortaldo JR, Harada A, Matsushima K, Kelvin DJ, Oppenheim JJ: Recombinant human interferon-inducible protein 10 is a chemoat- tractant for human monocytes and T lymphocytes and promotes $\mathrm{T}$ cell adhesion to endothelial cells. J Exp Med 1993;177:1809-1814.

$\checkmark 40$ Taub DD, Longo DL, Murphy WJ: Human interferon-inducible protein-10 induces mononuclear cell infiltration in mice and promotes the migration of human T lymphocytes into the peripheral tissues and human peripheral blood lymphocytes-SCID mice. Blood 1996;87:1423-1431.

41 Park JW, Gruys ME, McCormick K, Lee JK, Subleski J, Wigginton JM, Fenton RG, Wang JM, Wiltrout RH: Primary hepatocytes from mice treated with IL-2/IL-12 produce $\mathrm{T}$ cell chemoattractant activity that is dependent on monokine induced by IFN- $\gamma$ (Mig) and chemokine responsive to $\gamma-2$ (Crg-2). J Immunol 2001;166:3763-3770.

42 Laing KJ, Secombes CJ: Chemokines. Dev Comp Immunol 2004;28:443-460.

43 Wang X, Yue TL, Ohlstein EH, Sung CP, Feuerstein GZ: Interferon-inducible protein-10 involves vascular smooth muscle cell migration, proliferation, and inflammatory response. J Biol Chem 1996;271:2428624293.

44 Neville LF, Abdullah F, McDonnell PM, Young PR, Feuerstein GZ, Rabinovici R: Mob-1 expression in IL-2-induced ARDS: regulation by TNF- $\alpha$. Am J Physiol 1995; 269:L884-L890.

45 Lloyd AR, Oppenheim JJ, Kelvin DJ, Taub DD: Chemokines regulate $\mathrm{T}$ cell adherence to recombinant adhesion molecules and extracellular matrix proteins. J Immunol 1996;156: 932-938.

46 Kanda N, Watanabe S: Histamine inhibits the production of interferon-induced protein of $10 \mathrm{kDa}$ in human squamous cell carcinoma and melanoma. J Invest Dermatol 2002;119: 1411-1419.

47 Majumder S, Zhou LZ, Chaturvedi P, Babcock G, Aras S, Ransohoff RM: Regulation of human IP-10 gene expression in astrocytoma cells by inflammatory cytokines. J Neurosci Res 1998;54:169-180.

48 Varley CL, Armitage S, Hassanshahiraviz G, Dickson AJ: Regulation of the C-X-C chemokine, mob-1, gene expression in primary rat hepatocytes. Cytokine 2003;23:64-75.

49 Han B, Logsdon CD: Cholecystokinin induction of mob-1 chemokine expression in pancreatic acinar cells requires NF- $\mathrm{\kappa B}$ activation. Am J Physiol 1999;277(pt 1):C74-C82.

50 Han B, Logsdon CD: CCK stimulates mob-1 expression and NF- $\mathrm{KB}$ activation via protein kinase $\mathrm{C}$ and intracellular $\mathrm{Ca}^{2+}$. Am J Physiol Cell Physiol 2000;278:C344-C351.

-51 Kaplan G, Luster AD, Hancock G, Cohn ZA: The expression of a gamma interferon-induced protein (IP-10) in delayed immune responses in human skin. J Exp Med 1987;166: 1098-1108.

52 Romagnani P, Lazzeri E, Lasagni L, Mavilia C, Beltrame C, Francalanci M, Rotondi M, Annunziato F, Maurenzig L, Cosmi L, Galli G, Salvadori M, Maggi E, Serio M: IP-10 and Mig production by glomerular cells in human proliferative glomerulonephritis and regulation by nitric oxide. J Am Soc Nephrol 2002;13: 53-64.

53 Majumder S, Zhou LZ, Chaturvedi P, Babcock G, Aras S, Ransohoff RM: p48/STAT$1 \alpha$-containing complexes play a predominant role in induction of IFN- $\gamma$-inducible protein, $10 \mathrm{kDa}$ (IP-10) by IFN- $\gamma$ alone or in synergy with TNF-a. J Immunol 1998;161:4736-4744.

54 Kopydlowski KM, Salkowski CA, Cody MJ, van Rooijen N, Major J, Hamilton TA, Vogel $\mathrm{SN}$ : Regulation of macrophage chemokine expression by lipopolysaccharide in vitro and in vivo. J Immunol 1999;163:1537-1544.

55 Ubogu EE, Cossoy MB, Ransohoff RM: The expression and function of chemokines involved in CNS inflammation. Trends Pharmacol Sci 2006;27:48-55.

56 Muller DM, Pender MP, Greer JM: Chemokines and chemokine receptors: potential therapeutic targets in multiple sclerosis. Curr Drug Targets Inflamm Allergy 2004;3:279-290.

57 Buttmann $M$, Merzyn C, Rieckmann P: Interferon- $\beta$ induces transient systemic IP10/CXCL10 chemokine release in patients with multiple sclerosis. J Neuroimmunol 2004;156:195-203.

58 Gutierrez-Ramos JC, Lloyd C, Gonzalo JA: Eotaxin: from an eosinophilic chemokine to a major regulator of allergic reactions. Immunol Today 1999;20:500-504.

-59 Sørensen TL, Tani M, Jensen J, Pierce V, Lucchinetti C, Folcik VA, Qin S, Rottman J, Sellebjerg F, Strieter RM, Frederiksen JL, Ransohoff RM: Expression of specific chemokines and chemokine receptors in the central nervous system of multiple sclerosis patients. J Clin Invest 1999;103:807-815.

60 Simpson JE, Newcombe J, Cuzner ML, Woodroofe MN: Expression of the interferon- $\gamma$ inducible chemokines IP-10 and Mig and their receptor, CXCR3, in multiple sclerosis lesions. Neuropathol Appl Neurobiol 2000; 26:133-142.

-61 Sørensen TL, Sellebjerg F, Jensen CV, Strieter RM, Ransohoff RM: Chemokines CXCL10 and CCL2: differential involvement in intrathecal inflammation in multiple sclerosis. Eur J Neurol 2001;8:665-672.

62 Karkamandi H, Hosseini-zijoud S, Hosseini J: Genetic variation at the CXC chemokine IP10 (CXCL10) in parallel with its increased serum level in south-eastern Iranian multiple sclerosis patients. AAM 2012;1:71-76.

63 Abousaidi H, Vazirinejad R, Arababadi MK, Rafatpanah H, Pourfathollah AA, Derakhshan R, Daneshmandi S, Hassanshahi G: Lack of association between chemokine receptor 5 (CCR5) 832 mutation and pathogenesis of asthma in Iranian patients. South Med J 2011; 104:422-425.

64 Asadikaram G, Asiabanha M, Sayadi A, Jafarzadeh A, Hassanshahi G: Impact of opium on the serum levels of TGF- $\beta$ in diabetic, addicted and addicted-diabetic rats. Iran J Immunol 2010;7:186-192. 
65 Scarpini E, Galimberti D, Baron P, Clerici R, Ronzoni M, Conti G, Scarlato G: IP-10 and MCP-1 levels in CSF and serum from multiple sclerosis patients with different clinical subtypes of the disease. J Neurol Sci 2002;195: 41-46.

-66 Sprenger H, Rösler A, Tonn P, Braune HJ, Huffmann G, Gemsa D: Chemokines in the cerebrospinal fluid of patients with meningitis. Clin Immunol Immunopathol 1996;80:155-161.

- 67 Franciotta D, Martino G, Zardini E, Furlan R, Bergamaschi R, Andreoni L, Cosi V: Serum and CSF levels of MCP-1 and IP-10 in multiple sclerosis patients with acute and stable disease and undergoing immunomodulatory therapies. J Neuroimmunol 2001;115:192-198.

-68 Comini-Frota ER, Teixeira AL, Angelo JP, Andrade MV, Brum DG, Kaimen-Maciel DR, Foss NT, Donadi EA: Evaluation of serum levels of chemokines during interferon- $\beta$ treatment in multiple sclerosis patients: a 1-year, observational cohort study. CNS Drugs 2011;25:971-981.

-69 Sørensen TL, Trebst C, Kivisäkk P, Klaege KL, Majmudar A, Ravid R, Lassmann H, Olsen DB, Strieter RM, Ransohoff RM, Sellebjerg F: Multiple sclerosis: a study of CXCL10 and CXCR3 co-localization in the inflamed central nervous system. J Neuroimmunol 2002; 127:59-68.

-70 Christophi GP, Christophi JA, Gruber RC, Mihai C, Mejico LJ, Massa PT, Jubelt B: Quantitative differences in the immunomodulatory effects of Rebif and Avonex in IFN- $\beta$ 1a treated multiple sclerosis patients. J Neurol Sci 2011;307:41-45.

71 Satoh J, Nanri Y, Tabunoki H, Yamamura T: Microarray analysis identifies a set of CXCR3 and CCR2 ligand chemokines as early IFN $\beta$ responsive genes in peripheral blood lymphocytes in vitro: an implication for IFN $\beta$-related adverse effects in multiple sclerosis. BMC Neurol 2006;6:18.
72 Wandinger KP, Stürzebecher CS, Bielekova B, Detore G, Rosenwald A, Staudt LM, McFarland HF, Martin R: Complex immunomodulatory effects of interferon- $\beta$ in multiple sclerosis include the upregulation of $\mathrm{T}$ helper 1-associated marker genes. Ann Neurol 2001; 50:349-357.

73 Comabella M, Imitola J, Weiner HL, Khoury SJ: Interferon- $\beta$ treatment alters peripheral blood monocytes chemokine production in MS patients. J Neuroimmunol 2002;126:205212.

74 Sellebjerg F, Frederiksen JL, Nielsen PM, Olesen J: Double-blind, randomized, placebocontrolled study of oral, high-dose methylprednisolone in attacks of MS. Neurology 1998;51:529-534.

75 Sellebjerg F, Christiansen M, Jensen J, Frederiksen JL: Immunological effects of oral high-dose methylprednisolone in acute optic neuritis and multiple sclerosis. Eur J Neurol 2000;7:281-289.

-76 Rudick RA, Cookfair DL, Simonian NA, Ransohoff RM, Richert JR, Jacobs LD, Herndon RM, Salazar AM, Fischer JS, Granger CV, Goodkin DE, Simon JH, Bartoszak DM, Bourdette DN, Braiman J, Brownscheidle CM, Coats ME, Cohan SL, Dougherty DS, Kinkel RP, Mass MK, Munchsauer FE, O’Reilly K, Priore RL, Whitham RH, et al: Cerebrospinal fluid abnormalities in a phase III trial of Avonex (IFN $\beta$-1a) for relapsing multiple sclerosis. The Multiple Sclerosis Collaborative Research Group. J Neuroimmunol 1999;93:8-14.

77 Mellergård J, Edström M, Vrethem M, Ernerudh J, Dahle C: Natalizumab treatment in multiple sclerosis: marked decline of chemokines and cytokines in cerebrospinal fluid. Mult Scler 2010;16:208-217.
8 Ransohoff RM, Hamilton TA, Tani M, Stoler MH, Shick HE, Major JA, Estes ML, Thomas DM, Tuohy VK: Astrocyte expression of mRNA encoding cytokines IP-10 and JE/ MCP-1 in experimental autoimmune encephalomyelitis. FASEB J 1993;7:592-600.

-79 Azin H, Vazirinejad R, Ahmadabadi BN, Khorramdelazad H, Zarandi ER, Arababadi MK, Karimabad MN, Shamsizadeh A, Rafatpanah H, Hassanshahi G: The SDF-1 3'A genetic variation of the chemokine SDF-1a (CXCL12) in parallel with its increased circulating levels is associated with susceptibility to MS: a study on Iranian multiple sclerosis patients. J Mol Neurosci 2012;47:431436.

80 Salmaggi A, Gelati M, Dufour A, Corsini E, Pagano S, Baccalini R, Ferrero E, Scabini S, Silei V, Ciusani E, de Rossi M: Expression and modulation of IFN- $\gamma$-inducible chemokines (IP-10, Mig, and I-TAC) in human brain endothelium and astrocytes: possible relevance for the immune invasion of the central nervous system and the pathogenesis of multiple sclerosis. J Interferon Cytokine Res 2002;22: 631-640.

81 Poggi A, Catellani S, Fenoglio D, Borsellino G, Battistini L, Zocchi MR: Adhesion molecules and kinases involved in $\gamma \delta$ T cells migratory pathways: implications for viral and autoimmune diseases. Curr Med Chem 2007;14: 3166-3170.

82 Buttmann M, Goebeler M, Toksoy A, Schmid S, Graf W, Berberich-Siebelt F, Rieckmann P: Subcutaneous interferon- $\beta$ injections in patients with multiple sclerosis initiate inflammatory skin reactions by local chemokine induction. J Neuroimmunol 2005;168:175-182.

83 Revesz T, Kidd D, Thompson AJ, Barnard RO, McDonald WI: A comparison of the pathology of primary and secondary progressive multiple sclerosis. Brain 1994;117(pt 4):759765. 